\title{
Efektivitas Hybrid e-Learning Mata Kuliah Kimia Klinik dan Bioanalisis di Fakultas Farmasi Universitas Gadjah Mada
}

\author{
Effectiveness of Hybrid e-Learning in Clinical Chemistry and Bioanalysis Course in Faculty of Pharmacy \\ Universitas Gadjah Mada
}

\author{
Adam Hermawan $^{1^{*}}$, Muthi lkawati ${ }^{1}$, Susi Ari Kristina ${ }^{2}$, Edy Meiyanto ${ }^{1}$ \\ 1. Departemen Kimia Farmasi, Fakultas Farmasi, Universitas Gadjah Mada \\ 2. Departemen Farmasetika, Fakultas Farmasi, Universitas Gadjah Mada \\ Submitted: 1-16-2019 Revised: 3-24-2019 \\ Accepted: 8-8-2019 \\ Korespondensi : Adam Hermawan : Email : adam_apt@ugm.ac.id
}

\begin{abstract}
ABSTRAK
Seiring dengan perkembangan teknologi informasi metode e-learning merupakan salah satu pilihan untuk mengatasi keterbatasan waktu dan tempat. Mata kuliah Kimia Klinik dan Bioanalisis yang meliputi kuliah dan praktikum memiliki keterbatasan waktu praktikum, serta waktu dan tempat diskusi antara dosen pengampu kuliah dengan mahasiswa, oleh karena itu perlu adanya inovasi metode pembelajaran. Penelitian ini bertujuan untuk mengevaluasi efektivitas metode hybrid e-learning terhadap tingkat pemahaman mahasiswa serta mengevaluasi persepsi dan penerimaan mahasiswa terhadap metode hybrid e-learning pada mata kuliah Kimia Klinik dan Bioanalisis. Platform yang digunakan untuk pelaksanaan metode hybrid e-learning adalah elisa (elisa.ugm.ac.id) yang dikembangkan oleh Pusat Inovasi dan Kajian Akademik (PIKA) Universitas Gadjah Mada (UGM). Sebanyak 54 mahasiswa Fakultas Farmasi UGM semester VI tahun akademik 2017/2018, berpartisipasi dalam kegiatan pembelajaran ini. Diskusi online dilakukan dengan memberikan suatu artikel ilmiah atau data setelah suatu mata acara praktikum. Dosen juga memberikan tugas maupun kuis online melalui eLisa setiap 2 sampai 3 pekan sekali tergantung kesesuaian materi kuliah yang diberikan. Tugas maupun kuis online dibuka selama 24 jam setelah kuliah berlangsung. Metode hybrid e-learning meningkatkan pemahaman dan nilai mahasiswa berupa peningkatan nilai A sebesar 100 \% dibandingkan dengan metode konvensional. Sebagian besar mahasiswa merasa puas dan menikmati proses pembelajaran dengan hybrid e-learning menggunakan eLisa. Metode hybrid e-learning mampu meningkatkan pemahaman mata kuliah dan mahasiswa puas terhadap implementasi pembelajaran mata kuliah. Pengembangan lebih lanjut sebagai upaya penyempurnaan metode e-learning diperlukan untuk meningkatkan kualitas hasil pembelajaran.

Kata kunci: hybrid e-learning; Kimia Klinik dan Bioanalisis; farmasi; efektivitas pembelajaran; persepsi
\end{abstract}

\section{ABSTRACT}

The e-learning method has emerged over the years along with the development of information technology. One of the advantages of this method is not depending on space and time of lecture. The course of clinical chemistry and bioanalysis consisting of lectures and practical courses has time and place limitations for practical and discussion between lecturers and students, therefore learning method innovation is needed. This study aimed to evaluate the effectiveness of the hybrid e-learning method using elisa on student, as well as understanding and evaluating student perceptions and acceptance of the hybrid e-learning method in clinical chemistry and bioanalysis courses. The platform for the the hybrid e-learning method is eLisa (elisa.ugm.ac.id), developed by the Center for Innovation and Academic Studies (PIKA) UGM. A total of 54 UGM Pharmacy students in the sixth semester of the academic year 2017/2018 participated in this learning activity. Online discussion was conducted on a scientific paper or data obtained from practical courses. Lecturers also provide assignments and online quizzes through elisa every 2 to 3 weeks. Online assignments and quizzes are opened 24 hours after the lectures. The hybrid elearning method improve student's understanding on the lectures and results in the increased number of students who get A marks by $100 \%$ compared to conventional learning methods. Most students were satisfied and able to enjoy the learning process with hybrid e-learning with elisa. This method is able to improve the understanding of subjects and students are satisfied with the implementation of course learning. Further development on improving e-learning methods is needed to improve the quality of learning outcomes. 
Keywords: hybrid e-learning; clinical chemistry and bioanalysis; pharmacy; effectiveness of learning; perception

\section{PENDAHULUAN}

Pilihan metode pembelajaran mempengaruhi efektivitas pembelajaran dan tingkat pemahaman mahasiswa. Pembelajaran dapat dilakukan dengan tatap muka di kelas (metode pembelajaran konvensional) berfokus pada penyampaian materi oleh dosen (teacher centered learning) maupun kegiatan belajar mandiri mahasiswa (student centered learning) dengan dosen sebagai fasilitator. Selain itu metode pembelajaran juga dapat dilakukan dengan metode cooperative learning dan collaborative learning. Seiring pesatnya perkembangan teknologi informasi metode pembelajaran e-learning merupakan salah satu pilihan yang banyak dilakukan, karena berbagai keuntungan antara lain dapat dilakukan dimanapun dan kapanpun tanpa terbatas oleh ruang dan waktu 1,2. Berbagai platform pembelajaran e-learning juga telah berkembang baik yang gratis maupun berbayar seperti Coursera, Udacity, EdX 3,4, maupun Moodle, Blackboard, Kanexa, efront dan Acatar ${ }^{5}$. Meskipun beberapa merupakan produk berbayar, platform e-learning tadi dipandang efisien secara biaya dan waktu, serta efektif digunakan untuk transfer ilmu ${ }^{5}$. Universitas Gadjah Mada telah mengembangkan platform untuk e-learning yaitu eLisa (eLearning System for Academic Community) serta eLok yang digunakan untuk implementasi Massive Open Online Course (MOOC).

Mata kuliah Kimia Klinik dan Bioanalisis, terdiri dari 2 satuan kredit semester (sks) kuliah dan 1 sks praktikum, diberikan kepada mahasiswa Program Sarjana Fakultas Farmasi Minat Sains dan Teknologi di semester VI tahun akademik 2017/2018 dan diajarkan untuk memenuhi standar kompetensi apoteker Indonesia tahun 2016 yaitu peningkatan kompetensi diri agar mahasiswa menguasai ilmu dan teknologi farmasi yang dibutuhkan serta mampu memanfaatkan teknologi yang sesuai untuk pengembangan profesi. Mata kuliah ini bertujuan memperkenalkan berbagai metode penetapan kadar senyawa endogen dalam tubuh dengan metode berbasis biokimia dan biologi molekuler, analisis aktivitas enzim, pengukuran kualitas produk biosimilar, serta deteksi biomarker. Selain itu, dari praktikum ini mahasiswa diharapkan mampu mengetahui dan memahami teknik analisis potensi dan keamanan bahan menggunakan sistem biologi, utamanya teknik bioassay menggunakan cell lines. Mengingat waktu pelaksanaan praktikum serta fasilitas laboratorium yang terbatas, banyaknya pekerjaan yang harus dilakukan saat acara praktikum, serta perlunya penyamaan persepsi antara dosen pengampu praktikum, maka perlu adanya pengayaan materi dan inovasi pembelajaran agar mahasiswa lebih memahami materi praktikum tersebut. Selain itu, inovasi pembelajaran dengan metode hybrid e-learning juga mengatasi masalah keterbatasan waktu dan tempat diskusi antara dosen pengampu kuliah dengan mahasiswa. Penugasan individu maupun kelompok yang dilakukan dengan hybrid e-learning mata kuliah Kimia Klinik dan Bioanalisis juga menunjang kompetensi apoteker di bidang kepemimpinan dan manajemen yang meliputi kemampuan mengelola tugas-tugas mandiri dan tugas-tugas kelompok, mengambil keputusan yang tepat berdasarkan informasi dan data, serta mampu bertanggung-jawab atas tugas mandiri atau kelompok.

Platform eLisa telah digunakan di Farmasi UGM sejak tahun 2011 utamanya untuk repository bahan kuliah serta kuis online. Pada study ini platform eLisa tidak hanya digunakan sebagai repository namun juga digunakan sebagai media pembelajaran hybrid e-learning mata kuliah Kimia Klinik dan Bioanalisis, terdiri dari pemberian tugas, kuis maupun diskusi online. Selain itu evaluasi efektivitas penggunaan eLisa di Fakultas Farmasi UGM belum pernah dilaporkan sebelumnya. Artikel ini bertujuan membahas 
Tabel I. Karakteristik mahasiswa

\begin{tabular}{ccc}
\hline Parameter & $\begin{array}{c}\text { Metode TCL } \\
(\mathbf{n = 3 9 )}\end{array}$ & $\begin{array}{c}\text { hybrid e-learning } \\
(\mathbf{n}=\mathbf{5 4})\end{array}$ \\
\hline Persentase Jenis kelamin & & \\
Pria & 25.64 & 37.04 \\
Wanita & 74.36 & 62.96 \\
Rata-rata usia & 21 & 20.5 \\
\hline
\end{tabular}

penerapan dan evaluasi metode hybrid e-learning pada mata kuliah Kimia Klinik dan Bioanalisis. Selain itu, artikel ini juga bertujuan untuk mengevaluasi bagaimana persepsi mahasiswa terhadap pelaksanaan metode hybrid e-learning. untuk mahasiswa farmasi, khususnya di Fakultas Farmasi UGM.

\section{METODE}

\section{Desain penelitian dan setting}

Desain post study digunakan untuk mengevaluasi efektivitas pembelajaran hybrid e-learning, yaitu metode pembelajaran kombinasi antara tatap muka di kelas dan diskusi maupun penugasan secara online. Studi ini dilakukan di Fakultas Farmasi, Universitas Gadjah Mada, Yogyakarta, Indonesia.

Kriteria inklusi adalah mahasiswa Farmasi, total sebanyak 54 orang (Tabel I) (37,04\% pria dan $62,96 \%$ wanita dengan ratarata usia 20,23 tahun), semester VI, minat Farmasi Sains Dan Teknologi terlibat dalam studi ini (Tabel I). Kriteria eksklusi adalah mahasiswa yang tidak memenuhi persentase kehadiran sebesar minimal 75\%. Metode hybrid e-learning dilakukan mulai tanggal 6 Februari 2018 sampai dengan 6 Juni 2018. Nilai akhir mata kuliah yang diselenggarakan dengan metode hybrid e-learning dibandingkan dengan nilai mata kuliah Kimia Klinik dan Bioanalisis tahun 2017 yang diselenggarakan metode konvensional, yaitu dengan tatap muka di kelas menggunakan metode teacher center learning (jumlah mahasiswa 39, 25,64\% pria dan $74,36 \%$ wanita).

\section{Pengembangan modul untuk hybrid e-learning}

Platform yang digunakan untuk kegiatan hybrid e-learning adalah eLisa (elisa.ugm.ac.id), dengan nama komunitas Kimia Klinik dan Bioanalisis, berisi materi perkuliahan, multimedia, pemberian tugas, kuis dan diskusi online. Pada kegiatan ini dikembangkan multimedia berupa 9 video tutorial praktium, bekerjasama dengan Tim Teknis Kanal Pengetahuan Fakultas Farmasi UGM (KPF) dan juga diunggah di kanal Youtube Kanal Pengetahuan Farmasi UGM. Link multimedia juga diunggah di komunitas eLisa Kimia Klinik dan Bioanalisis.

\section{Penerapan hybrid e-learning}

Mahasiswa harus bergabung ke komunitas eLisa Kimia Klinik dan Bioanalisis (Gambar 1) untuk dapat mengikuti praktikum dan mengakses semua materi pembelajaran. Sebelum praktikum, mahasiswa (per kelompok) membuat cara kerja praktikum di log book berdasarkan petunjuk praktikum serta video tutorial dengan bimbingan oleh dosen serta asisten laboratorium. Selanjutnya dosen menguji kesiapan mahasiswa akan materi praktikum yang akan dikerjakan, dan menilai log book. Setiap kelompok bertanggung jawab penuh atas satu mata praktikum tertentu (merancang desain metodologi praktikum, memeriksa ketersediaan alat dan bahan, serta membantu penyiapan bahan dan pelaksaanaan percobaan diluar jam praktikum apabila diperlukan, serta membuat laporan untuk acara praktikum yang menjadi 


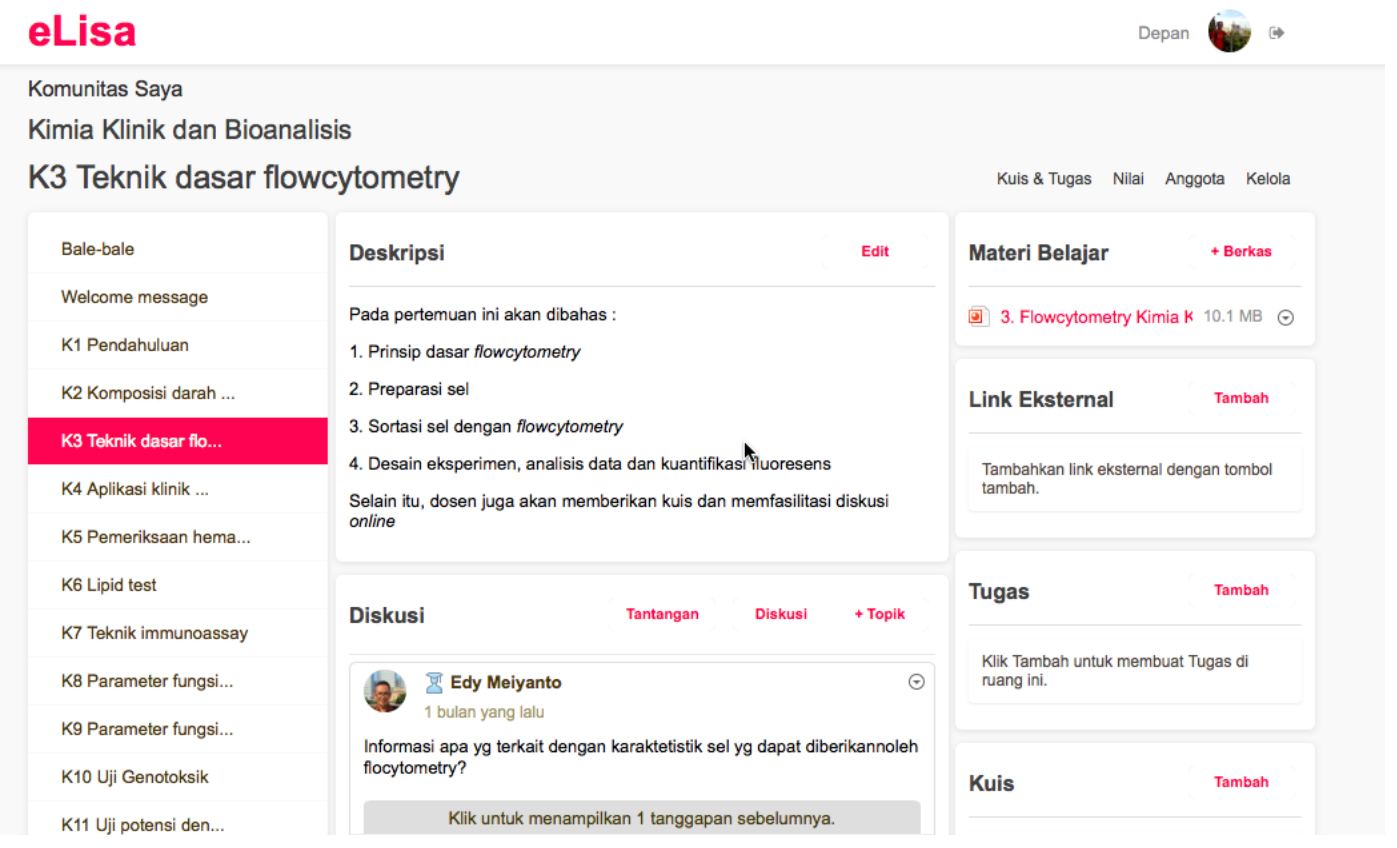

Gambar 1. Tampilan komunitas Kimia Klinik dan Bioanalisis di Platform eLisa

tanggung jawabnya), dan dibimbing oleh satu asisten penanggung jawab acara praktikum. Kelompok yang bertanggung jawab atas mata acara praktikum diwajibkan membuat dokumentasi atas cara kerja praktikum.

Setelah selesai melaksanakan praktikum, mahasiswa diwajibkan membuat laporan praktikum (laporan sementara perkelompok) yang memuat data-data praktikum dan perhitungan kadar dalam log book. Diskusi online dilakukan dengan memberikan suatu artikel ilmiah atau data setelah suatu mata acara praktikum. Dosen memberikan poin-poin pertanyaan yang dapat didiskusikan secara online. Diskusi untuk setiap materi dibuka sampai ujian akhir semester. Dosen memberikan penilaian terhadap keaktifan dan bobot isu diskusi untuk mahasiswa.

Untuk kegiatan perkuliahan, setelah dosen memberikan kuliah secara tatap muka di kelas, dosen akan memulai sesi diskusi online yang dibuka sampai ujian tengah semester (UTS) atau ujian akhir semester (UAS). Dosen juga memberikan tugas maupun kuis online melalui eLisa setiap 2 sampai 3 pekan sekali tergantung kesesuaian materi kuliah yang diberikan. Tugas maupun kuis online dibuka selama 24 jam setelah kuliah berlangsung. Baik UTS maupun UAS dilakukan dengan paper based testing (PBT).

\section{Evaluasi}

Evaluasi pemahaman mahasiswa dianalisis berdasarkan nilai kuis online, nilai responsi praktikum dan nilai akhir mata kuliah. Kuesioner dibuat oleh Pusat Inovasi dan Kajian Akademik (PIKA) UGM dan dibagikan kepada mahasiswa untuk mengevaluasi efektivitas pembelajaran dengan hybrid e-learning yang meliputi kualitas materi perkuliahan, kemudahan platform e-learning, serta sikap pengampu elearning. Kuesioner tersedia pada tautan http://ugm.id/17B. Kuesioner tersebut sudah melewati proses pengujian validitas yaitu content validity dengan dua ahli ilmu farmasi pendidikan, dan diuji cobakan kepada 20 mahasiswa non-responden sebagai tahapan face validity. Uji reliabilitas dilakukan dengan internal consistency Alpha Cronbach dengan hasil $\alpha>0,6$. Kuesioner juga sudah diterapkan di beberapa fakultas di UGM yang menggunakan platform eLisa. 
Tabel II. Tingkat Partisipasi kuis dan tugas online

\begin{tabular}{cc}
\hline Jenis aktivitas & Tingkat partisipasi (\%) \\
\hline Kuis 1 & 44.44 \\
Kuis 2 & 77.78 \\
Tugas 1 & 87.04 \\
Tugas 2 & 83.33 \\
\hline
\end{tabular}

Tabel III. Persentase nilai akhir mahasiswa

\begin{tabular}{lcc}
\hline \multirow{2}{*}{ Nilai } & \multicolumn{2}{c}{$\begin{array}{c}\text { Persentase mahasiswa yang memperoleh nilai akhir Kuliah Kimia } \\
\text { Klinik dan Bioanalisis dengan metode pembelajaran (\%) }\end{array}$} \\
\cline { 2 - 3 } & Metode TCL & Hybrid e-learning \\
\hline A & 23.08 & 46.30 \\
A- & 35.90 & 14.81 \\
A/B & 23.08 & 5.56 \\
B+ sampai K & 17.95 & 33.33 \\
Total & 100 & 100 \\
\hline
\end{tabular}

\section{Analisis data}

Data dianalisis menggunakan GraphPad Prism 5. Nilai $\mathrm{p}<0.05$ dianggap signifikan secara statistik. Selain itu dilakukan juga analisis naratif terhadap persepsi mahasiswa atas pelaksanaan hybrid e-learning.

\section{HASIL DAN PEMBAHASAN Penilaian pengetahuan mahasiswa}

Semua mahasiswa yang terlibat pada proses pembelajaran dengan hybrid e-learning memenuhi kriteria inklusi. Data statistik penggunaan komunitas belajar Kimia Klinik dan Bioanalisis adalah 669 kunjungan, 335 aktivitas diskusi, 2 kuis dan 2 tugas kelompok serta 59 bahan ajar yang meliputi slide materi kuliah, multimedia petunjuk praktikum, artikel ilmiah serta video penunjang pembelajaran. Sebanyak 90,7\% mahasiswa aktif dalam diskusi online. Tingkat partisipasi mahasiswa untuk mengerjakan kuis dan tugas online (Tabel II), serta nilai rata-rata kuis dan tugas online (Gambar 2) mengalami peningkatan seiring semakin seringnya mahasiswa mengakses komunitas eLisa. Nilai rata-rata kelas responsi praktikum (Gambar 3a) maupun nilai akhir rata-rata kelas (Gambar 3b) antara mahasiswa yang mengalami pembelajaran hybrid e-learning tidak berbeda signifikan dengan mahasiswa di tahun sebelumnya yang perkuliahannya diselenggarakan dengan tatap muka di kelas metode teacher center learning (TCL) di kelas. Meskipun demikian, terjadi peningkatan persentase nilai A sebesar $100 \%$ untuk nilai akhir mata kuliah dibandingkan dengan metode konvensional (Tabel III) pada mahasiswa yang mengalami pembelajaran dengan hybrid e-learning.

\section{Persepsi mahasiswa terhadap kualitas materi perkuliahan hybrid e-learning}

Terkait dengan kualitas materi untuk pembelajaran online, sebanyak 68,2\% mahasiswa setuju bahwa materi perkuliahan online relevan dengan topik perkuliahan, 45,5\% mahasiswa setuju membantu bahwa materi perkuliahan online mempermudah mahasiswa mencapai capaian pembelajaran, $33,3 \%$ mahasiswa setuju bahwa materi perkuliahan online menambah semangat belajar, 66,7\% mahasiswa setuju bahwa desain tampilan materi perkuliahan online menarik, serta 38,1\% mahasiswa setuju bahwa materi perkuliahan online mudah diakses. Video tutorial praktikum yang dikembangkan dari kegiatan ini juga mendapatkan respon yang bagus dari mahasiswa dan mampu meningkatkan pemehaman mereka akan praktikum yang akan dikerjakan. 


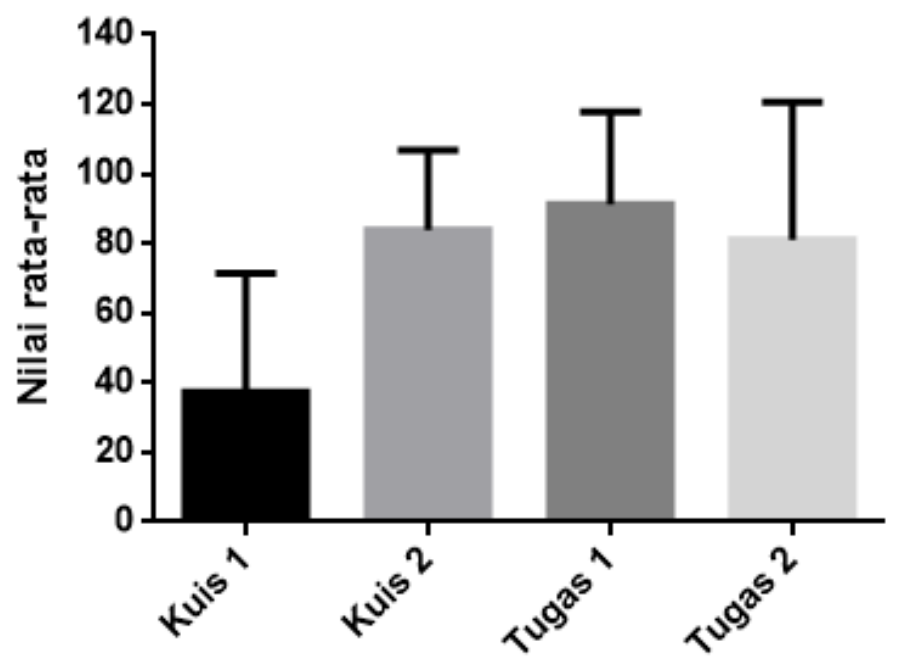

Gambar 2. NIlai rata-rata kuis dan tugas Kimia Klinik dan Bioanalisis pada metode hybrid elearning. Hasil merupakan rata-rata \pm SD $(n=54)$

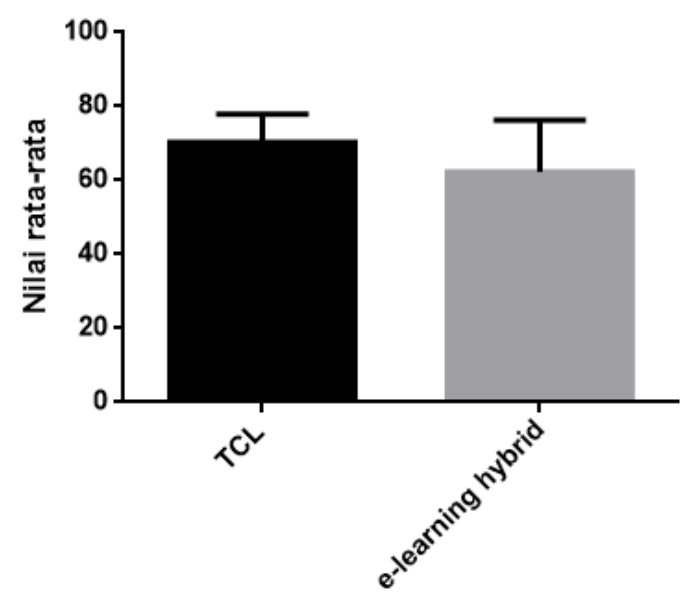

(a)

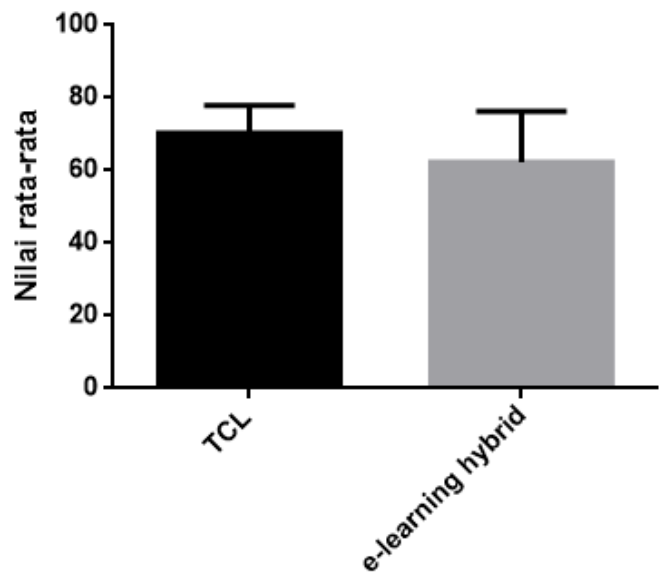

(b)

Gambar 3. Perbandingan nilai rata-rata responsi (A) dan nilai akhir mata kuliah (B) Kimia Klinik dan Bioanalisis dengan metode TCL $(n=39)$ dan hybrid e-learning $(n=54)$. Hasil merupakan ratarata \pm SD

Penggunaan teknologi visual akan mampu meningkatkan efektivitas pembelajaran ${ }^{6}$.

Selanjutnya mengenai penugasan online, sebanyak $66,7 \%$ mahasiswa setuju bahwa penugasan online relevan dengan topik perkuliahan, 38,1\% mahasiswa setuju bahwa penugasan online membantu pencapaian kompetensi belajar dan menambah semangat belajar, 42,9\% mahasiswa setuju bahwa penugasan online mudah ditemukan. Terkait dengan diskusi online, 66,7\% mahasiswa setuju bahwa diskusi online sangat relevan dengan topik perkuliahan, 52,4\% setuju bahwa diskusi online membantu memahami topik perkuliahan, serta 28,6\% setuju bahwa diskusi online menambah semangat belajar. 
Tabel IV. Kuesioner evaluasi metode hybrid e-learning tentang kualitas materi perkuliahan online.

\begin{tabular}{|c|c|c|c|c|c|}
\hline \multirow[b]{2}{*}{ Topik } & \multicolumn{5}{|c|}{ Persentase jawaban kuesioner mahasiswa } \\
\hline & $\begin{array}{l}\text { Sangat } \\
\text { Tidak } \\
\text { setuju }\end{array}$ & $\begin{array}{l}\text { Tidak } \\
\text { Setuju }\end{array}$ & Biasa & Setuju & $\begin{array}{l}\text { Sangat } \\
\text { setuju }\end{array}$ \\
\hline $\begin{array}{l}\text { Relevansi materi perkuliahan online dengan } \\
\text { topik perkuliahan }\end{array}$ & 4,5 & 0 & 13,6 & 68,2 & 18,2 \\
\hline $\begin{array}{l}\text { Materi perkuliahan online membantu dalam } \\
\text { memperoleh capaian pembelajaran }\end{array}$ & 4,5 & 0 & 45,5 & 45,5 & 4,5 \\
\hline $\begin{array}{l}\text { Materi perkuliahan online menambah } \\
\text { semangat belajar }\end{array}$ & 4,8 & 4,8 & 47,6 & 33,3 & 9,5 \\
\hline $\begin{array}{l}\text { Desain tampilan materi perkuliahan online } \\
\text { menarik }\end{array}$ & 0 & 4,8 & 9,5 & 66,7 & 19 \\
\hline Materi perkuliahan online mudah diakses & 0 & 4,8 & 23,8 & 38,1 & 33,3 \\
\hline $\begin{array}{l}\text { Penugasan online relevan dengan topik } \\
\text { perkuliahan }\end{array}$ & 0 & 0 & 23,8 & 66,7 & 9,5 \\
\hline $\begin{array}{l}\text { Penugasan online membantu pencapaian } \\
\text { kompetensi belajar }\end{array}$ & 4,8 & 0 & 47,6 & 38,1 & 9,5 \\
\hline Penugasan online menambah semangat belajar & 4,8 & 4,8 & 52,4 & 38,1 & 4,8 \\
\hline Penugasan online mudah ditemukan & 0 & 4,8 & 28,6 & 42,9 & 23,8 \\
\hline $\begin{array}{l}\text { Relevansi diskusi online dengan topik } \\
\text { perkuliahan }\end{array}$ & 0 & 0 & 23,8 & 66,7 & 9,5 \\
\hline $\begin{array}{l}\text { Diskusi online membantu memahami topik } \\
\text { perkuliahan }\end{array}$ & 4,8 & 0 & 38,1 & 52,4 & 4,8 \\
\hline Diskusi online menambah semangat belajar & 4,8 & 9,5 & 52,4 & 28,6 & 9,5 \\
\hline
\end{tabular}

\section{Persepsi mahasiswa terhadap kemudahan platform elisa yang digunakan pada perkuliahan hybrid e-learning}

Berdasarkan kuesioner mahasiswa terkait kemudahan penggunaan platform elearning (Tabel V), terlihat 55\% mahasiswa setuju bahwa fitur belajar online mudah ditemukan, 47,6 \% setuju bahwa fitur belajar online mudah diakses untuk diskusi, dapat digunakan dengan cepat dan lancar baik di dalam maupun di luar lingkungan UGM. Selain itu 52,4\% mahasiswa setuju bahwa mereka mudah melakukan registrasi di platform belajar online .

\section{Persepsi mahasiswa terhadap performa dosen pengampu perkuliahan hybrid e-learning}

Hasil survei mahasiswa terkait dengan performa dosen pengampu e-learning (Tabel VI) menunjukkan bahwa 47,6\% mahasiswa setuju akan adanya umpan balik konstruktif dosen terhadap penugasan online, sebanyak $42,9 \%$ mahasiswa setuju bahwa dosen memberikan respon yang cepat dengan penugasan online dan $57,1 \%$ mahasiswa setuju bahwa dosen memberikan nilai tugas/kuis tidak dalam waktu yang lama (sekitar 1 minggu). Selanjutnya sebanyak 61,9\% mahasiswa setuju akan adanya umpan balik kontrsuktif dosen terhadap diskusi online, serta 55\% mahasiswa setuju akan adanya umpan balik dosen terhadap diskusi online dalam waktu singkat (sekitar 1 minggu).

Artikel ini mengevaluasi penerapan metode hybrid e-learning pada mata kuliah Kimia Klinik dan Bioanalisis. Kegiatan hybrid e-learning meningkatkan pemahaman mahasiswa berdasarkan peningkatan persentasi jumlah mahasiswa yang mendapatkan nilai A, dibandingkan persentase mahasiswa dengan nilai $\mathrm{A}$ pada 
Tabel V. Hasil Kuesioner tentang kemudahan platform hybrid e-learning.

\begin{tabular}{|c|c|c|c|c|c|}
\hline \multirow[b]{2}{*}{ Topik } & \multicolumn{5}{|c|}{ Persentase jawaban kuesioner mahasiswa } \\
\hline & $\begin{array}{l}\text { Sangat } \\
\text { Tidak } \\
\text { setuju }\end{array}$ & $\begin{array}{l}\text { Tidak } \\
\text { Setuju }\end{array}$ & Biasa & Setuju & $\begin{array}{l}\text { Sangat } \\
\text { setuju }\end{array}$ \\
\hline Fitur belajar online mudah ditemukan & 0 & 0 & 25 & 55 & 20 \\
\hline Kemudahan akses diskusi online & 0 & 0 & 38.1 & 47.6 & 14.3 \\
\hline Fitur belajar online mudah dioperasikan & 0 & 0 & 33.3 & 47.6 & 19 \\
\hline $\begin{array}{l}\text { Fitur belajar dapat digunakan dengan cepat } \\
\text { dan lancar di lingkungan UGM }\end{array}$ & 0 & 0 & 23.8 & 47.6 & 28.6 \\
\hline $\begin{array}{l}\text { Fitur belajar dapat digunakan dengan cepat } \\
\text { dan lancar di luar lingkungan UGM }\end{array}$ & 0 & 9.5 & 28.6 & 47.6 & 14.3 \\
\hline Kemudahan registrasi & 0 & 0 & 28.6 & 52.4 & 19 \\
\hline
\end{tabular}

Tabel VI. Hasil kuesioner terkait pengampu hybrid e-learning.

\begin{tabular}{|c|c|c|c|c|c|}
\hline \multirow[b]{2}{*}{ Topik } & \multicolumn{5}{|c|}{ Persentase jawaban kuesioner mahasiswa } \\
\hline & $\begin{array}{l}\text { Sangat } \\
\text { Tidak } \\
\text { setuju }\end{array}$ & $\begin{array}{l}\text { Tidak } \\
\text { Setuju }\end{array}$ & Biasa & Setuju & $\begin{array}{l}\text { Sangat } \\
\text { setuju }\end{array}$ \\
\hline $\begin{array}{l}\text { Umpan balik konstruktif dosen terhadap } \\
\text { penugasan online }\end{array}$ & 0 & 19 & 14,3 & 47,6 & 23,8 \\
\hline $\begin{array}{l}\text { Dosen merespon dengan cepat penugasan } \\
\text { online }\end{array}$ & 0 & 19 & 14,3 & 42,9 & 23,8 \\
\hline $\begin{array}{l}\text { Dosen memberikan nilai tugas akhir dengan } \\
\text { cepat }\end{array}$ & 0 & 4,8 & 28,6 & 57,1 & 9,5 \\
\hline $\begin{array}{l}\text { Umpan balik konstruktif dosen terhadap } \\
\text { diskusi online }\end{array}$ & 0 & 0 & 9,5 & 61,9 & 28,6 \\
\hline $\begin{array}{l}\text { Umpan balik dosen terhadap diskusi online } \\
\text { dalam waktu singkat }\end{array}$ & 0 & 0 & 25 & 55 & 20 \\
\hline
\end{tabular}

metode TCL di tahun sebelumnya. Respon positif mahasiswa terhadap pelaksaan hybrid e-learning ini mendukung penelitianpenelitian sebelumnya yang menyebutkan bahwa pelaksanaan e-learning untuk mahasiswa Farmasi dapat meningkatkan pemahaman mereka materi perkuliahan yang diberikan $^{7-9}$.

Hambatan terbesar pada pelaksanaan kegiatan hybrid e-learning adalah kesibukan dari pengampu kuliah. Sehingga koordinator tim pelaksana hibah yang harus aktif mengingatkan dosen pengampu lain untuk memoderatori diskusi maupun meng-upload materi pembelajaran di komunitas eLisa.
Tingkat partisipasi mahasiswa untuk diskusi dan mengerjakan kuis serta tugas online di awal semester juga cukup rendah. Untuk meningkatkan tingkat partisipasi mahasiswa, diberikan hadiah berupa ATK dan kepada lima orang mahasiswa yang paling aktif diskusi online serta satu kelompok praktikum dengan performa terbaik (berdasarkan penilaian terhadap log book catatan kerja praktikum, aktivitas diskusi online, dan presentasi hasil praktikum). Untuk menyeragamkan pemahaman mahasiswa akan diskusi akhir hasil praktikum di semua golongan, pada forum diskusi akhir praktikum di kelas setiap kelompok diminta 
membuat notulensi yang diunggah di bagian diskusi komunitas eLisa sehingga semua mahasiswa dapat mengetahui materi diskusi yang dilakukan oleh golongan praktikum lainnya.

Studi tentang persepsi mahasiswa terhadap kualitas materi perkuliahan, kemudahan penggunaan platform eLisa, serta performa dosen pengampu perkuliahan online menunjukkan adanya respon positif mahasiswa terhadap kegiatan hybrid $e^{-}$ learning. Salah satunya karena platform online fleksibel untuk diakses kapanpun dan dimanapun mahasiswa berada. Hasil kegiatan ini menambah data keberhasilan pelaksanaan perkuliahan online di pendidikan Farmasi 8,10,11. Meskipun demikian ada beberapa saran untuk perbaikan fitur eLisa. Terkait dengan platform hybrid e-learning yang digunakan, fitur diskusi di platform eLisa juga masih belum memungkinkan untuk memberikan komentar secara langsung di bawah pertanyaan/komentar yang ingin ditanggapi (comment on comment). Selain itu integrasi platform elisa dengan media sosial akan membuat tampilan lebih menarik serta meningkatkan engagement mahasiswa terhadap perkuliahan online. Partisipasi mahasiswa yang mengisi kuesioner adalah $40 \%$ dari total mahasiswa yang memenuhi kriteria inklusi. Hal ini menjadi salah satu keterbatasan kami sehingga untuk penelitian selanjutnya mahasiswa diwajibkan mengisi kuesioner agar nilainya bisa dikeluarkan oleh tim pengampu mata kuliah. Selain itu keterbatasan studi ini adalah tidak adanya pengukuran pemahaman mahasiswa sebelum intervensi dengan pelaksanaan hybrid $e$ learning, sehingga ke depannya perlu juga dilakukan studi pre dan post test. Studi lanjutan dengan jumlah mahasiswa yang lebih banyak dan durasi waktu pelaksanaan yang lebih lama juga perlu dilakukan.

\section{KESIMPULAN}

Metode hybrid elearning ini cukup efektif dalam meningkatkan pemahaman dan nilai mahasiswa peserta mata kuliah Kimia Klinik dan Bioanalisis. Saran dan perbaikan terhadap fitur platform eLisa perlu dilakukan untuk meningkatkan semangat belajar mahasiswa.

\section{UCAPAN TERIMA KASIH}

Penulis mengucapkan terima kasih kepada Pusat Inovasi dan Kajian Akademik (PIKA) Universitas Gadjah Mada yang telah mendanai kegiatan Hibah e-learning menggunakan eLisa tahun 2018 dengan nomor kontrak No.003/SP/PIKA/2018.

\section{DAFTAR PUSTAKA}

1. Ali FR, Hassan F, Hasan SF, Israr F, Shafiq Y, Arshad HM. Short Communication: Perception and attitude of pharmacy students towards learning tools. Pak $J$ Pharm Sci. 2015;28(6):2185-2189.

2. Gubbiyappa KS, Barua A, Das B, Vasudeva Murthy CR, Baloch HZ. Effectiveness of flipped classroom with Poll Everywhere as a teaching-learning method for pharmacy students. Indian J Pharmacol. 2016;48(Suppl 1):S41-s46.

3. Liang J, Yang J, Wu Y, Li C, Zheng L. Big Data Application in Education: Dropout Prediction in Edx MOOCs. Paper presented at: 2016 IEEE Second International Conference on Multimedia Big Data (BigMM); 20-22 April 2016, 2016.

4. Liliyana FN, Svirina AA, Polina OR, Garanin DA, Lukashevich NS, Leventsov VA. TechnoMOOC development of the basis of remote lab access. Paper presented at: 2017 International Conference "Quality Management,Transport and Information Security, Information Technologies" (IT\&QM\&IS); 24-30 Sept. 2017, 2017.

5. Dodun O, Panaite E, Seghedin N, et al. Analysis of an E-learning Platform use by Means of the Axiomatic Design. Procedia CIRP. 2015;34:244-249.

6. Curley LE, Wu Z, Svirskis D. Using Technology in Pharmacy Education: Pharmacy Student Performance and Perspectives When Visual Aids Are 
Integrated Into Learning. Front Pharmacol. 2018;9:1062.

7. Isaacs AN, Nisly S, Walton A. Studentgenerated e-learning for clinical education. Clin teach. 2017;14(2):129-133.

8. Lean QY, Ming LC, Wong YY, Neoh CF, Farooqui M, Muhsain SNF. Validation of online learning in pharmacy education: Effectiveness and student insight. Pharm Educ. 2018;18.

9. Salter SM, Karia A, Sanfilippo FM, Clifford RM. Effectiveness of E-learning in pharmacy education. Am J Pharm Educ. 2014;78(4):83.
10. Karaksha A, Grant G, Nirthanan SN, Davey AK, Anoopkumar-Dukie S. A Comparative Study to Evaluate the Educational Impact of E-Learning Tools on Griffith University Pharmacy Students' Level of Understanding Using Bloom's and SOLO Taxonomies. Educ Res Intl. 2014;2014:11.

11. Leong C, Louizos C, Currie C, et al. Student perspectives of an online module for teaching physical assessment skills for dentistry, dental hygiene, and pharmacy students. J Interprof Care. 2015;29(4):383-385. 